\title{
Increasing numbers of medical undergraduates from lower socioeconomic backgrounds: positive for health care?
}

This article was published in the following Dove Press journal:

Advances in Medical Education and Practice

20 March 2013

Number of times this article has been viewed

\section{TI Lemon}

\section{B A Stone}

Cardiff University, School of Medicine, Cochrane Medical Education Centre, Heath Park, Cardiff, Wales
Correspondence: TI Lemon, clo 5th floor, Cochrane Medical Education Centre, University Hospital of Wales, Cardiff CFI4 4XW, Wales Email lemonti@cf.ac.uk; lemonti@ doctors.org.uk

\section{To the editor}

Economic stagnation in the UK has been a prominent issue for the last five years, leading to an increase in unemployment and a subsequent rise of numbers in the lower socioeconomic classes. ${ }^{1}$ Seyan et $\mathrm{al}^{2}$ have shown that students from the lower socioeconomic classes are under-represented in medical schools. However, their study was carried out in a time of economic prosperity, and we suggest that this is reversed in times of economic deprivation, to the benefit of patients.

Adaptation theory ${ }^{3}$ suggests that an organism suffering change in their environment will adapt to change and become better suited to survival. In this case, the organism is the adolescent population of the UK, the change in environment is the economic downturn, and in turn, their adaptation is to turn to professional jobs in order to provide themselves with secure income and live happier and healthier lives. Thus, it is reasonable to suggest that we will see growing numbers of medical students coming from the lower socioeconomic classes in the near future.

Consequently, numbers of doctors from more deprived areas of the population will increase as well. ${ }^{3}$ As greater proportions of the population start to suffer from health problems associated with socioeconomic deprivation, they will increasingly face a doctor who understands their background. Drawing from the Becker and Maiman ${ }^{4}$ health belief model, ideas, concerns, and expectations regarding health care will be more relevant to the doctor, and genuine empathy for patients will not only lead to greater patient satisfaction, but to greater patient compliance as well.

As we begin to see numbers of medical students from the lower socioeconomic classes increasing in the UK, ${ }^{5}$ we will also see the numbers of doctors with personal experience of the issues their patients face increase. The benefit to the patient will be that they have a doctor who understands and considers an issue that may be ignored or seen as insignificant by a doctor from a more privileged background. The benefit to the health care system is that these patients will receive better communication about their disease state, and thus be more likely to respond to prescriptions and lifestyle changes that will improve their health.

Therefore, the authors suggest that the economic stagnation we have suffered will have some positive outcomes for health care, because previous doctor-patient barriers are removed. There is the capacity for this to potentiate efficient health care and reduce expenditure on preventable diseases, a currently formidable challenge posed by those in the lower socioeconomic classes. 


\section{Acknowledgment}

We thank Lampard R, Shah R, and Yarrow-Jenkins A of the School of Medicine, Cardiff University, for their roles within an associated steering committee.

\section{Disclosure}

The authors report no conflicts of interest in this correspondence.

\section{References}

1. Brewer M, Phillips D, Sibieta L. What has happened to 'severe poverty' under Labour? Institute of Fiscal Studies, 2010 Election Briefing Note No 3 (IFS BN90). Available from: http://www.ifs.org.uk/bns/bn90.pdf. Accessed February 28, 2013.
2. Seyan K, Greenhalgh T, Dorling D. The standardised admission ratio for measuring widening participation in medical schools: analysis of UK medical schools admissions by ethnicity, socioeconomic status, and sex. BMJ. 2004;328:1545-1546.

3. Orr H. The genetic theory of adaption: a brief history. Nature. 2005;6: 119-127.

4. Becker M, Maiman L. Sociobehavioral determinants of compliance with health and medical care recommendations. Med Care. 1975;13:10-24.

5. Holmes D. Eight years' experience of widening access to medical education. Med Educ. 2002;36:979-984. 


\section{Author's response}

\section{Trisha Greenhalgh}

Correspondence: Trisha Greenhalgh

Global Health, Policy and Innovation

Unit, Centre for Primary Care

and Public Health, Blizard Institute,

Barts and The London School of Medicine and Dentistry, Yvonne Carter

Building, 58 Turner Street, London EI 2AB

Tel +440207882 7326

Fax +440207882 2552

Email p.greenhalgh@qmul.ac.uk

This is an interesting hypothesis. There are surely sufficient data available already to test this hypothesis, or at least look for a trend since economic austerity began to bite several years ago. I wish these authors (and other interested scientists) good luck in preparing a short paper or scientific letter presenting data in support of, or against, this hypothesis. Dr Seyan was a medical student when he did the original work using routinely available data, and scored a high mark in his student dissertation as well as being able to put a widely cited paper on his curriculum vitae. Others might follow this example, to the benefit of their own career and the wider knowledge base.

\section{Publish your work in this journal}

Advances in Medical Education and Practice is an international, peerreviewed, open access journal that aims to present and publish research on Medical Education covering medical, dental, nursing and allied healthcare professional education. The journal covers undergraduate education, postgraduate training and continuing medical education including emerging trends and innovative models linking education, research, and healthcare services. The manuscript management system is completely online and includes a very quick and fair peer-review system. Visit http://www.dovepress.com/testimonials.php to read real quotes from published authors.

Submit your manuscript here: http://www.dovepress.com/advances-in-medical-education-and-practice-journal 